\title{
BEHAVIOR AND STRENGTH OF GEOPOLYMER CASTELLATED COMPOSITE BEAMS
}

\section{"Dr. Waleed A.Waryosh ${ }^{1}$}

1) Assistant Prof., Civil Engineering Department, Mustansiriyah University, Baghdad, Iraq.

2) M.Sc. Student, Civil Engineering Department, Mustansiriyah University, Baghdad, Iraq
Ali S. Ali $^{2}$

\begin{abstract}
The difference between normal and polymer concrete not contain a hydrated cement phase. In present work, behavior and strength of the polymer concrete composite castellated beam with different openings shape by experimental approach are investigates. Ultimate load strength capacity and deformations of the composite beams specimens are explorations. Ultimate load strength capacity and deformations of the composite beams specimens are explorations. Different parameters are considered such as shape of openings for the castellated beam. Test results showed that the hexagon opening shape gave more strength capacity and less deflection. The full interaction gave more strength capacity and less deflection.

It was found that the percentage of increase in ultimate load for the specimen (Geopolymer composite castellated beam with opening $35 \%$ for Hexagonal shape with full interaction ) was about (83\%) for the reference specimen (Control Composite Castellated), as well as the specimen (Geopolymer composite castellated beam with opening $70 \%$ for Hexagonal shape with full interaction), it gave more durability than the reference specimen (Control Composite Castellated) with $48 \%$. As for the fourth model, (Geopolymer composite castellated beam with opening $70 \%$ for Rectangular shape with full interaction) gave higher durability than the reference specimen by $24 \%$.
\end{abstract}

Keywords: Geopolymer Concrete, Castellated Beam, Opening size, Composite Beam.

\section{Introduction}

A castellated steel beam is the beam in which contains spread a standard rolled steel section in such a way that a predetermined pattern is cut on section webs and the web opening may circular, hexagonal or octagonal. The two halves are joined reversal together by welding together so that the modulus section increased [1]. The advantages of castellated steel beam are high strength to weight ratio, cost wise and lighter section in additions it can be using the opening for servicing and mechanical ducts. The production of geopolymer concrete that adapted in experimental tests by chemical action from different materials such as inorganic or fly ash or other materials.. The aggregate of polymer concrete is bounded with each other by means of polymer binder. The difference between normal and polymer concrete not contain a hydrated cement phase. The production of geopolymer concrete made with the absence of ordinary cement. Rangan et al, 2006 [2], investigated the behavior of structural elements as beams and columns constructed by geopolymer concrete. Twenty four specimens 
represents the total tested beams and columns that twelve for each. The beams all are simply supported with span $(3 \mathrm{~m})$ that tested under four point's loads. Tests results indicated that the behavior of geopolymer concrete same as ordinary concrete but differ in mechanical properties and strength. Dattatreya et al, 2011 [3], looked out on the behavior and strength of flexural geopolymer concrete beams under static loads. The twelve beam dimension as $(100 \times 150$ $\mathrm{mm})$ with $\operatorname{span}(1.5 \mathrm{~m})$ that subjected to four point loads. The adopted concrete compressive strength of normal and geopolymer concrete are $(35,52)$ and (17-63) MPa. Test results showed that the strength load capacity in cases of geopolymer concrete was higher than normal and high strength concrete. Madheswaran et al, 2013 [4], explored different compressive strength and the presences of alkaline solutions that used in polymer concrete. a Cube specimen was used with dimensions as $(150 \times 150 \times 150$ $\mathrm{mm})$ and cylinder have dimensions of $(150 \mathrm{~mm}$ in diameter and $300 \mathrm{~mm}$ in height) to investigated the polymer concrete mechanical properties. Test results indicated that the mechanical properties of polymer concrete developed as increased in sodium hydroxide concentration. Girawale et al, 2015 [5], looked out on the mechanical properties of polymer concrete that compared with normal concrete. The main idea was to focused on the effects of alkaline on concrete properties. Different molarity ratios were selected such as $(12,14$ and 16 Molar). Test results showed that the polymer concrete increased as the molarity ratios increased and also there are enhanced in mechanical properties when compared with the normal concrete. Al-Attar et al., 2015 [6], optimized mix design of polymer concrete by adopted ten Molar of Alkaline. Different ratios of (sodium silicate/sodium hydroxide) such as (1.0 and 3.5) were selected. Twelve cubes with dimensions of $(150 \times 150 \times 150 \mathrm{~mm})$ were tested.
Test results indicated that the optimum dose of superplasticizer was $(12 \mathrm{~kg} / \mathrm{m} 3)$ that gave increased in compressive strength of concrete. Pirmoz and Daryan, 2008 [7], analyzed solid and castellated beams used nonlinear analysis by ANSYS software. Different parameters were considered such as beam span and bracings. Concluded by analysis results that the long span beams the rotation capacity decreased in case of castellated beam when compared with steel beams without openings. Gizejowski and Salah Khalil, 2010 [8], investigated the stability of the castellated composite beams under the effect of bending. Twelve composite beams represented the total specimens that adapted with parameters such as long span, short span and web perforation shapes like square, hexagonal and circular. Al-Saeedi, 2018 [9] investigated and evaluated self-compacted composite castellated beams under the effects of static and impact loads. Finite elements analysis was adapted to check out the experimental tested results. Sixteen specimens were tested with different parameters such as castellation percentages $(0$, $25,33.8$ and $50 \%$ ) in addition to used two types of concrete included self-compacted and normal concrete with different strengths. Test and experimental results showed that the composite castellated beams with self-compacted concrete have higher strength capacity and lower deflections as compared with the normal concrete. Elaiwi, 2019 [10], studied the influence of web openings of steel beams (castellated) on the lateral deflection and on the torsional buckling by two approached such as close form and numerical solution by ANSYS. The analysis included nonlinearities such as material and geometry of castellated beams and also studied the dynamic response of castellated beams. 


\section{Aim and Significant of Research}

Different tests for composite castellated steel beams with different opening size of web. Many researchers tested composite castellated steel beams but little or no investigations of geopolymer concrete that casted above the castellated steel beam. The aims and objectives of present study are to investigate the behaviors of polymer concrete composite castellated beam with different openings shape under the effect of four point's static loadings. Different web opening shapes such as hexagon and rectangular are adapted and the concrete slab type is polymer concrete in addition to the control beam without opening for comparisons. Composite beams capacity, deflections and strain for all tested specimens are recorded and discuses

\section{Materials}

Geopolymer concrete is made by reacting aluminate and silicate bearing materials with a caustic activator. The adapted material in present study as follow:

\subsection{Metakaolin}

The nature of the Metakaolin is clay mineral kaolinite and can produce by chemical compositions from Al2Si2O5 (OH)4. The methodology and processes to converting kaolinite to metakaolin relay on the applied temperature in which (100-200 Co) the most quantity of water will be loss and (500-700 Co) loss all water. Chemical, physical and the requirements based on the ASTM C618 [11] properties of Metakaolin are lists in Table (1), (2) and (3) respectively.
Table 1. Chemical properties of Metakaolin

\begin{tabular}{|c|c|}
\hline Oxide & \%Content \\
\hline $\mathrm{SiO}_{2}$ & 54.20 \\
\hline $\mathrm{Al}_{2} \mathrm{O}_{3}$ & 39.0 \\
\hline $\mathrm{Fe}_{2} \mathrm{O}_{3}$ & 0.92 \\
\hline $\mathrm{CaO}$ & 1.37 \\
\hline $\mathrm{MgO}$ & 0.15 \\
\hline $\mathrm{SO}_{3}$ & 0.45 \\
\hline $\mathrm{Na}_{2} \mathrm{O}$ & 0.22 \\
\hline $\mathrm{TIO}_{2}$ & 0.80 \\
\hline $\mathrm{K}_{2} \mathrm{O}$ & 0.71 \\
\hline
\end{tabular}

Table 2. Physical Properties of Metakaolin

\begin{tabular}{|l|l|}
\hline Physical Property & Results \\
\hline Physical form & Powder \\
\hline Color & Off-white \\
\hline Specific gravity & 2.64 \\
\hline Surface area, $\left(\mathrm{m}^{2} / \mathrm{g}\right)$ & 13.30 \\
\hline
\end{tabular}

Table 3. Chemical Requirements Based on ASTM C618 [11]

\begin{tabular}{|c|c|c|}
\hline Composition of Oxide & $\begin{array}{c}\text { Pozzolans, } \\
\text { Class N } \\
\end{array}$ & Metakaolin \\
\hline $\begin{array}{l}\% \text { min } \\
\mathrm{SiO}_{2}+\mathrm{Al}_{2} \mathrm{O}_{3}+\mathrm{Fe}_{2} \mathrm{O}_{3}\end{array}$ & 70.00 & 94.12 \\
\hline$\% \max \mathrm{SO}_{3}$ & 4.00 & 0.45 \\
\hline $\begin{array}{l}\% \max \text { Loss on } \\
\text { ignition }\end{array}$ & 10.00 & 0.71 \\
\hline
\end{tabular}

\section{2-SodiumSilicate}

The brand of sodium silicate adapted in present study manufactured in United Arab Emirate with properties by weight lists in Table(4).

Table 4. Sodium Silicate's Properties (supplier brochure)

\begin{tabular}{|l|l|}
\hline Description & Value \\
\hline $\mathrm{SiO}_{2} / \mathrm{a}_{2} \mathrm{O}$ & $2.4 \pm .05$ \\
\hline$\% \mathrm{H} 2 \mathrm{O}$ & 55.10 \\
\hline$\% \mathrm{Na} 2 \mathrm{O}$ & $13.10-13.70$ \\
\hline$\% \mathrm{SiO} 2$ & $32-33$ \\
\hline Density & $51 \pm 0.5$ \\
\hline Specific Gravity & $1.534-1.551$ \\
\hline Viscosity & $600-200$ \\
\hline
\end{tabular}

\subsection{Sodium Hydroxide}

The sodium hydroxide is the most important item to prepare the geopolymer concrete. The sodium hydroxide prepared by dissolved caustic 
soda flakes in water. The chemical reaction between sodium hydroxide and water was an exothermic component after that the compositions cool in air for two hour. Table (5) lists the test results and compare with the requirements based on ASTM E 291-09 [12].

Table 5. Properties Sodium Hydroxide

\begin{tabular}{|c|c|c|}
\hline Appearance & $\begin{array}{l}\text { Test } \\
\text { results }\end{array}$ & $\begin{array}{l}\text { Specification ASTM } \\
\text { E291-09 [12 ] }\end{array}$ \\
\hline $\begin{array}{l}\text { \%Sodium } \\
\text { hydroxide }(\mathrm{NaOH})\end{array}$ & 98.14 & $\geq 97.5$ \\
\hline $\begin{array}{l}\text { \%Sodium } \\
\text { carbonate } \\
\left(\mathrm{Na}_{2} \mathrm{CO}_{3}\right)\end{array}$ & 0.36 & $\leq 0.40$ \\
\hline $\begin{array}{l}\text { Sodium chloride } \\
(\mathrm{NaCl}),\left(\mathrm{P}_{\mathrm{Pm}}\right)\end{array}$ & 70.00 & $\leq 200$ \\
\hline Iron as $\mathrm{Fe}^{+3},\left(\mathrm{P}_{\mathrm{Pm}}\right)$ & 4.50 & $\leq 10$ \\
\hline $\begin{array}{l}\text { Sulphates as } \\
\mathrm{Na}_{2} \mathrm{SO}_{4},\left(\mathrm{P}_{\mathrm{Pm}}\right)\end{array}$ & 70.00 & $\leq 200$ \\
\hline $\begin{array}{l}\text { Copper as } \mathrm{Cu}^{+2} \text {, } \\
\left(\mathrm{P}_{\mathrm{Pm}}\right)\end{array}$ & 0.10 & $\leq 4.00$ \\
\hline $\begin{array}{l}\text { Nickel as } \mathrm{Ni}^{+2} \text {, } \\
\left(\mathrm{P}_{\mathrm{Pm}}\right)\end{array}$ & 2.42 & $\leq 5.00$ \\
\hline $\begin{array}{l}\text { Manganese as } \\
\mathrm{Mn}^{+2},\left(\mathrm{P}_{\mathrm{Pm}}\right)\end{array}$ & 0.02 & $\leq 4.00$ \\
\hline $\begin{array}{l}\text { Silicate as } \mathrm{SiO}_{2}, \\
\left(\mathrm{P}_{\mathrm{Pm}}\right)\end{array}$ & 14.00 & $\leq 20.00$ \\
\hline $\begin{array}{l}\text { Water Insoluble, } \\
\left(\mathrm{P}_{\mathrm{Pm}}\right)\end{array}$ & 60.00 & $\leq 200.00$ \\
\hline
\end{tabular}

The methodology that adapted to prepared alkaline solution by prepared from the $(\mathrm{NaOH})$ and (Na2SiO3) by dissolve flaky high purity sodium hydroxide more or equal to $(98 \%)$ in distilled water. One litter solution was prepared by mixed $(560 \mathrm{~g})$ of $(\mathrm{NaOH})$ with $(826 \mathrm{ml})$ water so that the concentration by weight is (0.404). The Molarity (mole/l) for adopted mix was (14) and the weight of $(\mathrm{NaOH})$ flakes is (404 g).The preparation of alkaline liquid by mixed one litter from $(\mathrm{NaOH})$ with (3.5 litter) from $\left(\mathrm{Na}_{2} \mathrm{SiO}_{3}\right)$. The adopted time mix was (1 day) before use the final mixture [6].

\section{Geopolymer Concrete Mix - Methodology}

The adapted methodology in present experimental tests [6] for geopolymer concrete that producing by mixing silica and aluminum oxide in the Metakaolin that react with the alkaline (that is mean composition of $\mathrm{Na} 2 \mathrm{SiO} 3$ with $\mathrm{NaOH}$ ) to prevent the slips between the fine and coarse aggregates to male them as unity. First of all, the fine and coarse aggregates are placed in saturated place with dry condition. The time interval is three minutes to mix the fine and coarse aggregates together by mixer. After the aggregates mixed, the metakaolin then added to the mixture and sterling with time period two minutes. Water and Superplasticizer and then this mix is added to the aggregates mixed and sterling with time around two minutes. The percentage of superplasticizer and water (65\% water and $35 \%$ superplasticizer) was mixed uniformly through five minutes and then added to the final mix.

The mechanical properties of geopolymer such as compressive strength, splitting tensile strength, modulus of rupture and modulus of elasticity are explored; Table (6) Mix proportion of geopolymer concrete for deck slab, Table(7) lists the summary of mechanical properties.

Table 6. Mix proportion of geopolymer concrete for deck slab

\begin{tabular}{|c|c|}
\hline Material & Geopolymer concrete [6] \\
\hline Metakaoline $(\mathrm{kg})$ & 400 \\
\hline Sand $(\mathrm{kg})$ & 720 \\
\hline Gravel $(\mathrm{kg})$ & 1100 \\
\hline Alkaline $(\mathrm{kg} / \mathrm{m} 3)$ & 180 \\
\hline Superstabilizer $(\mathrm{kg})$ & 3 (\% of metakaolin) \\
\hline Water & 10(\% of metakaolin) \\
\hline
\end{tabular}

Table7. Summary of Mechanical Properties Geopolymer Concrete

\begin{tabular}{|l|l|}
\hline Age (Days) & 28 \\
\hline Compressive strength $f c^{\prime}(\mathrm{MPa})$ & 32.60 \\
\hline Splitting tensile strength $(\mathrm{MPa})$ & 4.55 \\
\hline Modulus of rupture $(\mathrm{MPa})$ & 4.46 \\
\hline
\end{tabular}




\section{Composite Castellated Beams Details}

The composite castellated beams details configuration is shown in Figure (1). Table (8) lists the whole specimen dimensions (4) composite castellated steel beams were tested under static loading

Table 8. Composite castellated steel specimens

\begin{tabular}{|c|c|c|c|}
\hline Specimen & Opening shape & $\begin{array}{c}\% \\
\text { opening } \\
\text { size }\end{array}$ & Descriptions \\
\hline GFS00 & --- & 0 & $\begin{array}{c}\text { No opening- } \\
\text { Solid }\end{array}$ \\
\hline GFH35 & Hexagonal & 35 & $80.82 \mathrm{~mm}$ \\
\hline GFH70 & Hexagonal & 70 & $161.65 \mathrm{~mm}$ \\
\hline GFR70 & Rectangular & 70 & $242.4 \mathrm{~mm}$ \\
\hline & & & \\
\hline
\end{tabular}

G: Geopolymer, S: Solid, H: Hexagonal, R: Rectangular, F: Full interaction,

R70

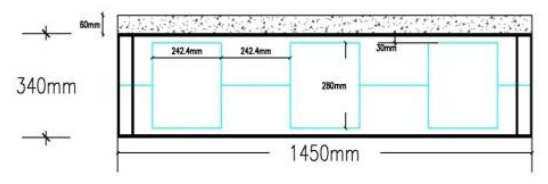

$\mathrm{H70}$

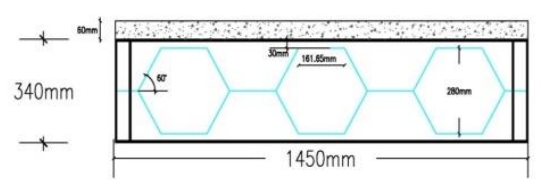

H35

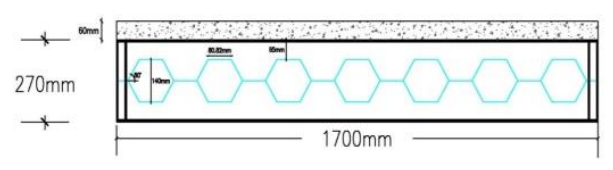

SOO

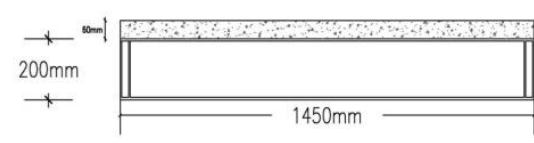

Figure 1. Composite Castellated Beams Configurations and Details.

\section{Load-Deflections Behavior}

In general, all specimens were tested up to failure in which the failure occurred in concrete slab due to cracks propagations. The specimens behaved as linear started from zero up to load that caused first crack in concrete slab that rely on the concrete type, full interaction and opening web of steel beam percentage. The behavior of the specimens after the point of inflection becomes nonlinear due to change in modulus of elasticity that influenced by increase in load that cause increase in strain that reflects in reduction on the magnitude of modulus of elasticity so that the specimen stiffness become less. Increase in load makes the slop of the load deflection less that indicates reduce in specimen stiffness due to increase in load and deflections. The deflection at the mid span gave the maximum value due to the curvature of the beam increase started from zero deflection at supports.

The reference specimen (GFS00) solid web without openings cast by geopolymer concrete with number of stud shear connectors make the composite beam as full interaction, the ultimate load capacity is $(143 \mathrm{kN})$ and the corresponding deflection at mid span is $(7.80 \mathrm{~mm})$. The behavior of reference CCB start from zero up to $(31.50 \mathrm{kN})$ that represent the load caused first crack is linear. The maximum deflection at the mid and quarter of the GFS00 is (7.80 and 3.12 $\mathrm{mm}$ ) respectively.

The specimen (GFH35) with openings (35\%) from the web height that cast by geopolymer concrete and provided sufficient stud shear connectors so that it works as full interaction. The shape of opening is hexagon, in which the test showed that the ultimate load resistances reach $(262.5 \mathrm{kN})$. The behavior is linear up to (28\%) from the failure load that represents the first crack loading. Particularly, the decreased in 
beam stiffness due to increase in displacements that lead to increase in strain then reduce in concrete modulus of elasticity. The deflection at quarter and mid span of the beam is (1.86 and $9.65 \mathrm{~mm}$ ) respectively and the load caused first crack is $(74.0 \mathrm{kN})$.

The specimen (GFH70), the load capacity is $(212.50 \mathrm{kN})$ compared with the (GFH35) there was reduced in strength and approximately same maximum deflection.

The specimen (GFR70), the load capacity is $(177.5 \mathrm{kN})$ compared with the specimen (GFH35) there was reduced in strength and in deflection due to the percentage of web opening more that make decrease in stability. The reduced in deflection due to that increase in opening change the load transformation.

Load-deflection curves of the tested CCB at quarter and mid span at all stages of loading up to failure are constructed and shown in Figures (2) to (3).

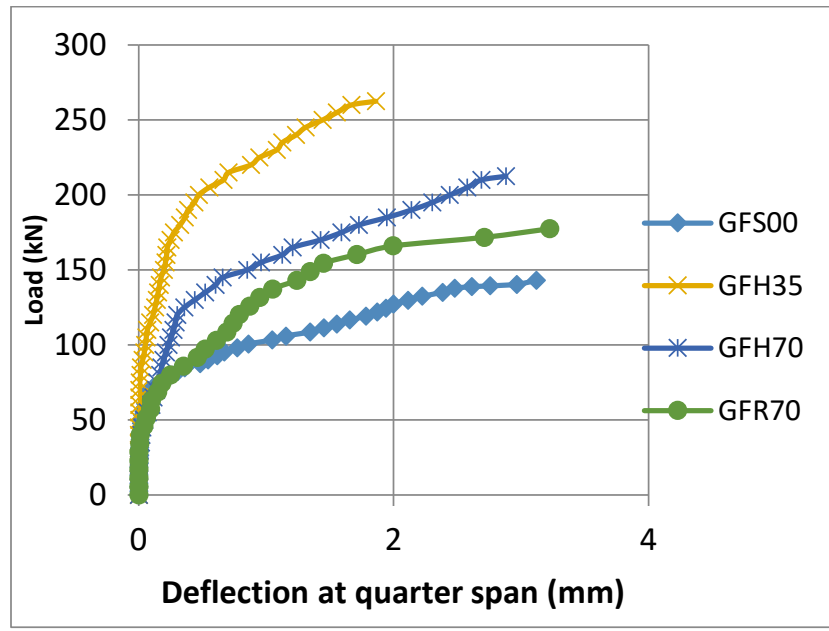

Figure 2. Load - deflection for all specimens - quarter span

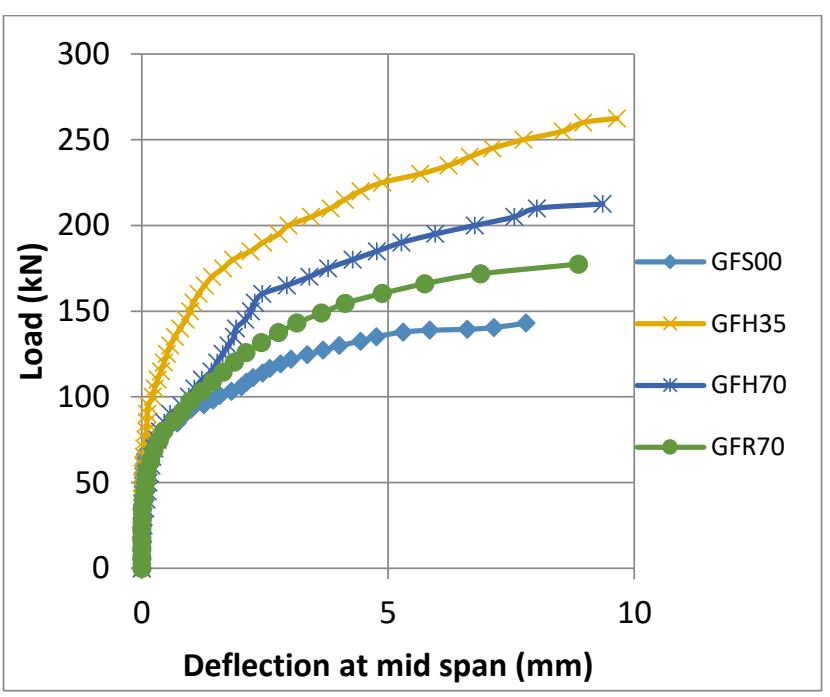

Figure 3. Load - deflection for all specimens - Mid span

\section{Strains Behavior}

Strains were measured at the location at middle of bottom flange, mid web and mid reinforced geopolymer concrete slab. The functions of measured strains that developed in steel section and concrete are to evaluate the strain behavior of the reinforced geopolymer concrete composite castellated beams under the effects of static loadings and find out which material yield first. Figure (4) shows the load - strain behavior for all specimens. All behavior start as linear with small increments in strain up to approximately $(75 \%)$ from the ultimate load. the behavior of the models become nonlinear (curve) when the load reach the ultimate load capacity. All recorded strain in the tension zone not reach the yielding strain (0.00175) so that the steel section not yield and still in the elastic zone 


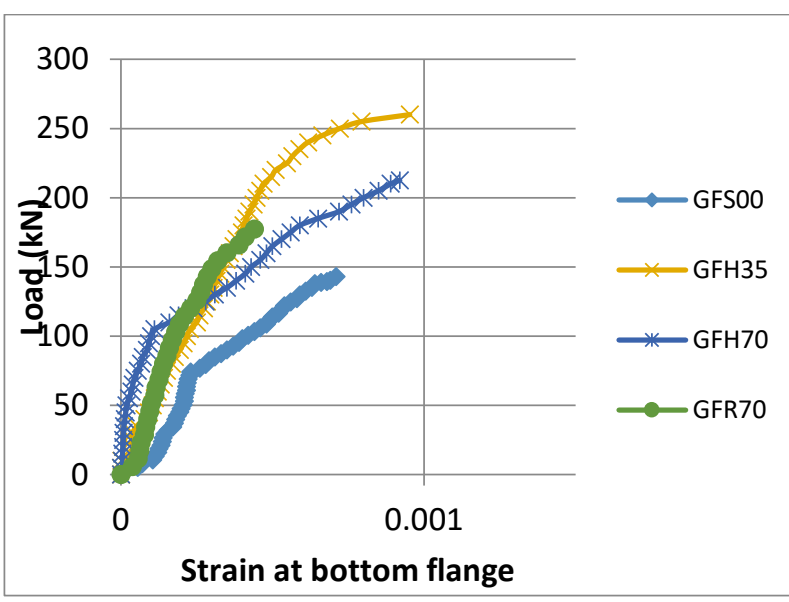

Figure 4. Load - strain at middle bottom steel flange

Figure (5) represents the full behavior of the load - strain for all specimens that recorded in the middle web of steel section. The midpoints of web lie in the tension zone of the composite castellated beam and all strains within the elastic range that not exceeded the yielding strain that mentioned above. All loads - strain behave as elastic up to ultimate load for each specimen.

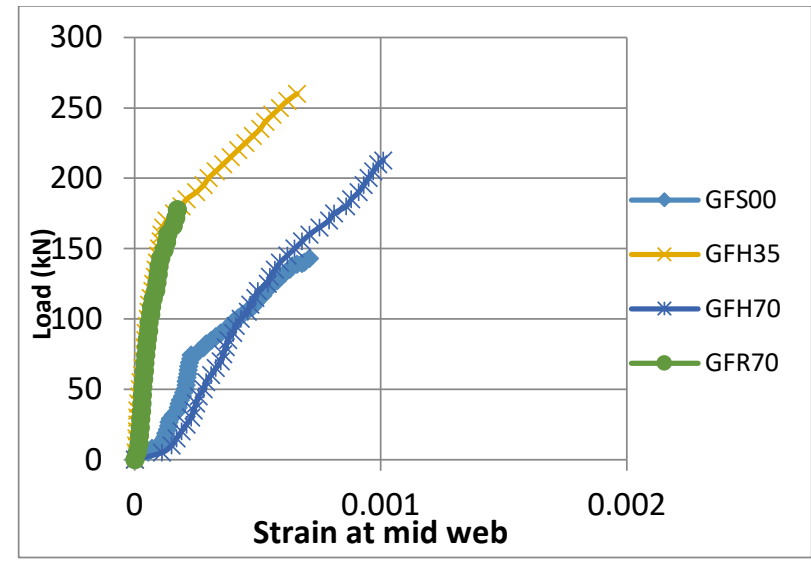

Figure 5. Load - strain at mid web - all specimens

Figure (6) shows the load - strain at the middle of the reinforced geopolymer concrete slab for each specimen. The behavior of load - strain starts as linear up to nearly first crack that relies on the each specimen specification. After first cracks of each specimens, the behaviors become nonlinear but still in elastic range. All specimens not reach the maximum strain in concrete (0.003) based on ACI-318 - 2019 [13] except specimens GFH70 and GFR70 that explained the failure due to heavy cracks.

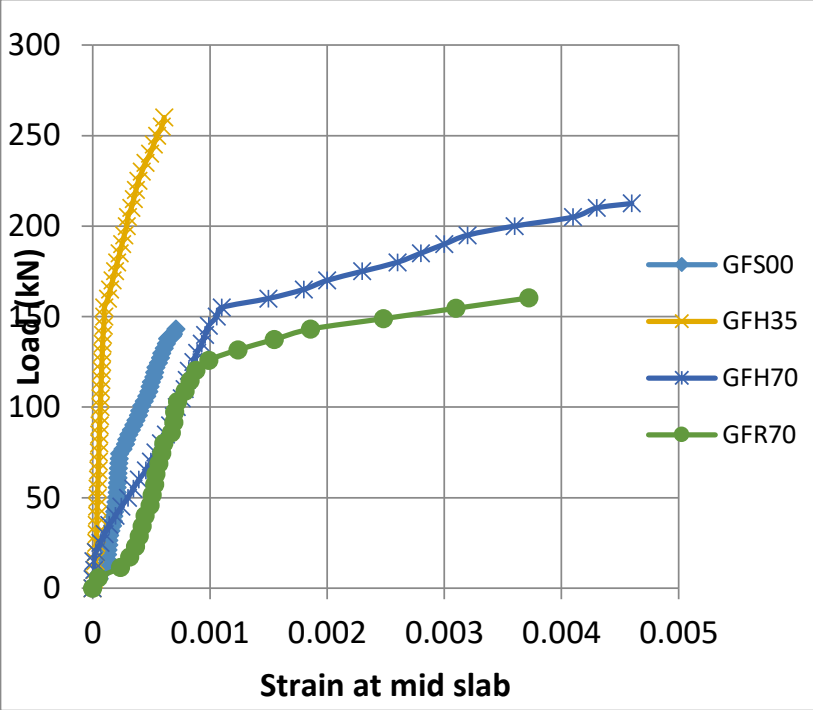

Figure 6. Load - strain at mid concrete slab

\section{Cracks and mode of failure}

A Plate (1) to (4) shows the cracks propagations and failure modes for all composite castellated beams. No pull - out of concrete slab failure and there is no cut of any headed stud shear connectors during test up to ultimate loads for each specimen. The specimen GFS00 is shown in Plate (1) in which the cracks at failure stage show nearly vertical and parallel to slab thickness started from the locations of applied loads toward slab bottom. The specimens GFH35 shown in Plate (2), the cracks intensity at failure load are more than GFS00 and close recorded ultimate load and maximum deflection. While the specimen GFH70 is shown in Plate (3) has cracks at failure more than GFS00

A Plate (4) shows the crack propagation of specimens GFR70 at failure stage respectively. The amount of cracks intensity with low failure load indicated that this specimen fail when the cracks in the slab growth more quickly due to weakness of the composite castellated beam due to large openings size 


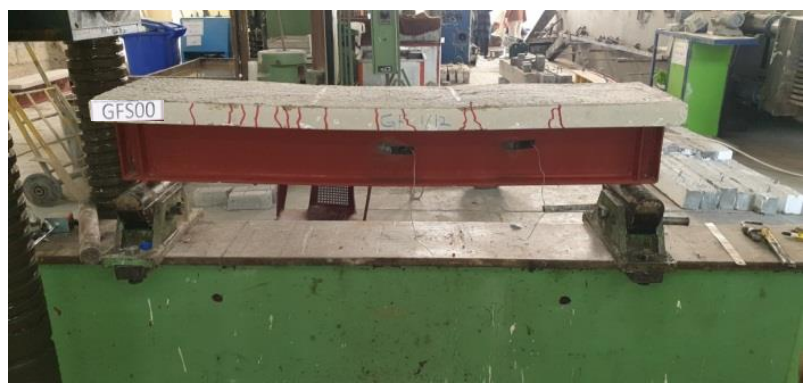

Plate 1. Cracks propagations of specimen GFS00 at failure stage

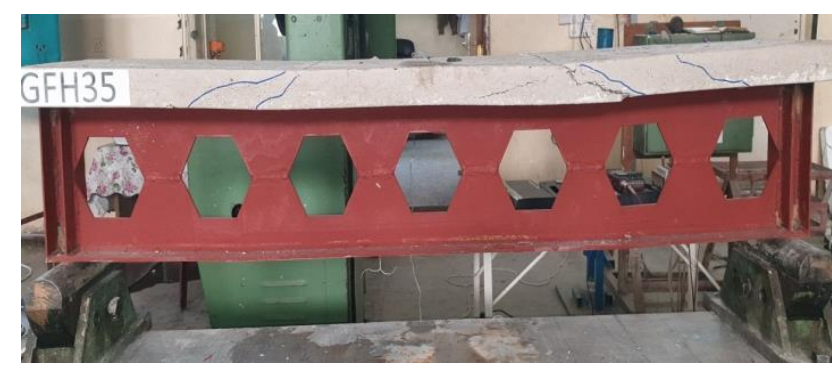

Plate 2. Cracks propagations of specimen GFH35 at failure stage

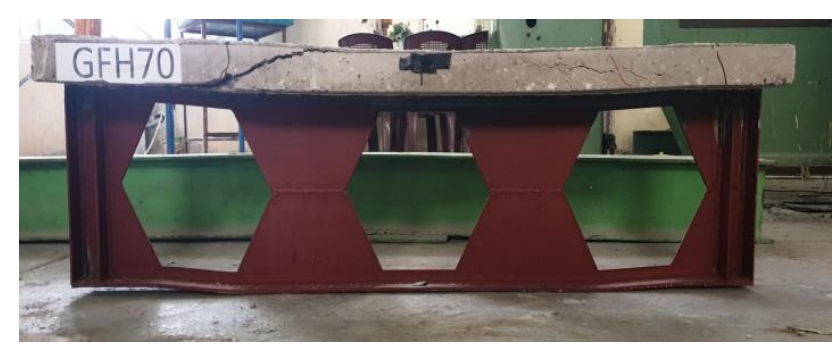

Plate 3. Cracks propagations of specimen GFH70 at failure stage

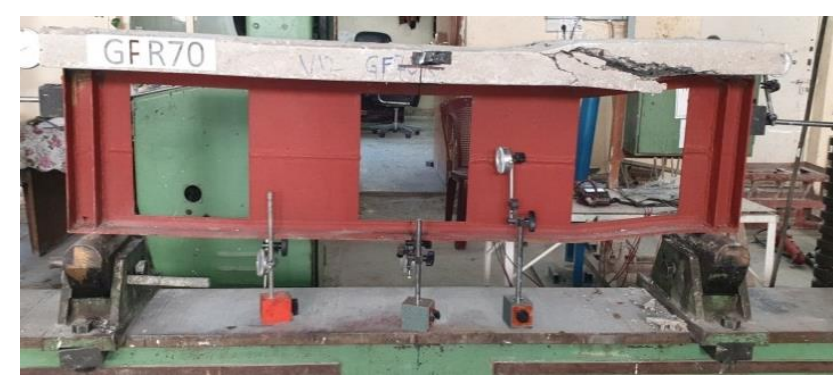

Plate 4. Cracks propagations of specimen GFR70 at failure stage

\section{Discussions}

According to the experimental investigation with different parameters that adopted in present work such as opening size and opening shapes, followings are discussions due to observations and test results.

\subsection{Effects of opening on the strength capacity of specimens}

The presence of openings effects on the strength capacity of the specimens. Table (9) lists the effects of openings on ultimate load, maximum deflection that occurred at ultimate load. The control specimen beam GFS00 is solid, other specimens differed in castellated beam dimensions. Increase in steel depth (in case of presences openings) increase in load strength capacity and also reduce deflection due to increase in moment of inertia and so on beam stiffness.

Table 9. Effects of openings on ultimate load, deflection of composite castellated beams.

\begin{tabular}{|c|c|c|c|c|}
\hline $\begin{array}{c}\text { Specime } \\
\mathrm{n} \text { mark }\end{array}$ & $\begin{array}{c}\text { Ultimate } \\
\text { load } \\
(\mathrm{kN})\end{array}$ & $\begin{array}{c}\% \\
\text { Increases } \\
\text { in ultimate } \\
\text { load }\end{array}$ & $\begin{array}{c}\text { Maximu } \\
\mathrm{m} \\
\text { deflectio } \\
\mathrm{n} \text { at mid } \\
(\mathrm{mm})\end{array}$ & $\begin{array}{c}\% \\
\text { Decrea } \\
\text { se in } \\
\text { deflect } \\
\text { ion }\end{array}$ \\
\hline GFS00 & 143.0 & --- & 7.80 & --- \\
\hline GFH35 & 262.5 & 83.57 & 0.95 & 87.82 \\
\hline GFH70 & 212.5 & 48.60 & 2.21 & 71.67 \\
\hline GFR70 & 177.5 & 24.13 & 3.15 & 59.62 \\
\hline
\end{tabular}

\subsection{Effects of opening shape}

Table (10) lists the comparisons between the specimens as a function of opening shape as hexagon and rectangular. In case of rectangular opening, the diagonal distance between the edges of opening greater than that in hexagon so those large openings reduce the strength load capacity of whole section. The forms of hexagons especially (oblique) the diagonal works like rib that increase the strength and stability of the section. 
Table 10. Effects of opening shape on ultimate load, deflection of composite castellated beams.

\begin{tabular}{|c|c|c|c|c|}
\hline $\begin{array}{c}\text { Specim } \\
\text { en } \\
\text { mark }\end{array}$ & $\begin{array}{c}\text { Ultimate } \\
\text { load } \\
(\mathrm{kN})\end{array}$ & $\begin{array}{c}\% \\
\text { Increases } \\
\text { in ultimate } \\
\text { load }\end{array}$ & $\begin{array}{c}\text { Maximum } \\
\text { deflection } \\
\text { at mid } \\
(\mathrm{mm})\end{array}$ & $\begin{array}{c}\% \\
\text { Decre } \\
\text { ase in } \\
\text { deflec } \\
\text { tion }\end{array}$ \\
\hline GFR70 & 177.5 & --- & 8.87 & --- \\
\hline GFH70 & 212.5 & 19.72 & 3.86 & 56.48 \\
\hline
\end{tabular}

9.3. Effects of opening size on the strength capacity of specimens

Two percentages of openings size with respect to the web area such as $(35 \%$ and $70 \%)$ are investigated. Increase in opening percentage that is mean increased in openings area lead to reduce in strength load capacity and increase in deflection and slip due to reduce in moment of inertia that reflect on the beam stiffness. Table (11) lists the effects of opening size on ultimate load, deflection and slip of composite castellated beam.

Table 11. Effects of opening size on ultimate load, deflection of composite castellated beams.

\begin{tabular}{|c|c|c|}
\hline Specimen mark & GFH70 & GFH35 \\
\hline $\begin{array}{c}\text { Ultimate load } \\
(\mathrm{kN})\end{array}$ & 212.5 & 262.5 \\
\hline $\begin{array}{c}\text { Maximum } \\
\text { deflection at quarter } \\
(\mathrm{mm})\end{array}$ & 2.88 & 1.86 \\
\hline $\begin{array}{c}\text { \% Increases in } \\
\text { ultimate load }\end{array}$ & --- & 3.83 \\
\hline $\begin{array}{c}\text { Maximum } \\
\text { deflection at mid } \\
\text { (mm) }\end{array}$ & 9.36 & 59.08 \\
\hline $\begin{array}{c}\text { \% Decrease in } \\
\text { deflection }\end{array}$ & --- & \\
\hline
\end{tabular}

\section{Conclusions}

Based on the results from experimental tests, followings are the important conclusions points:

1. The specimens haves rectangular opening, the diagonal distance between the edges of opening greater than that in hexagon so those large openings reduce the strength load capacity of the composite castellated beams.

2. Increasing percentage lead to reduce in strength load capacity and increase in deflection and slip due to reduce in moment of inertia that reflect on the beam stiffness.

3. Full interaction between the two contact surface as top of steel castellated beam and reinforced concrete slab worked and act as unity. In case of full interaction the number of shear stud connectors becomes more so that the shear flow transfer between the two contact surfaces distributed to the shear connectors less that lead to reduce slip and deflection and the composite beam capacity become more than partial system.

\section{Conflict of interest}

The authors undertake that the publication of this article does not cause any conflict of interest.

\section{References}

1. Marmors Group, Metal trade and construction, "Castellated beams" http://www.marmorsgroup.com/steelstructures/castellated-beams

2. Sumajouw, M. D. J. and Rangan, B. V. (2006). "LOW-CALCIUM FLY ASHBASED GEOPOLYMER CONCRETE: REINFORCED BEAMS AND COLUMNS",Research Report GC 3, Faculty 
of Engineering, Curtin University of Technology, Perth, Australia

3. Dattatreya, J. K., Rajamane, N. P., Sabitha, D, Ambily, P. S. and Nataraja M.C.(2011)."Flexural behavior of reinforced Geopolymer concrete beams",INTERNATIONAL JOURNAL OF CIVIL AND STRUCTURAL ENGINEERING, Volume 2, No 1.

4. Madheswaran, C. K., Gnanasundar, G., Gopalakrishnan, N.(2013). "Effect of molarity in geopolymer concrete", INTERNATIONAL JOURNAL OF CIVIL AND STRUCTURAL ENGINEERING Volume 4, No 2.

5. Girawale, M. S. (2015) ., "EFFECT'S OF ALKALINE SOLUTION ON GEOPOLYMER CONCRETE", International Journal of Engineering Research and General Science, ISSN 20912730, Volume 3, Issue 4.

6. Al-Attar, T. S., Al-Shathr, B. S., and Hasan, Z. A.(2015). "Optimization of Geopolymer Concrete Based on Local Iraqi Metakaolin", The 2nd International Conference of Buildings, Construction and Environmental Engineering BCEE2, pp97-100.

7. Pirmoz, A. and Daryan, A. S.(2008). "Nonlinear Behavior of Castellated Beams Subjected to Moment Gradient Loading", Special Report, Civ. Eng. Dept., Toosi Univ. Technol.

8. Marian A. Gizejowski and Wael A. Salah Khalil.(2010)."STABILITY AND DUCTILITY OF CASTELLATED COMPOSITE BEAMS SUBJECTED TO HOGGING BENDING", SDSS'Rio 2010 STABILITY AND DUCTILITY OF STEEL STRUCTURES, E. Batista, P. Vellasco, L. de Lima (Eds.), Rio de Janeiro, Brazil.

9. Alsaeedi, S. Q. A. G.(2018). "Experimental and Finite Element Investigation for Structure Behavior of Composite Self
Compacting Concrete Castellated Steel Beams Subjected to Static and Impact Loads", MSc. Thesis, University of Technology / Civil Engineering Department.. 10. Elaiwi, S. S.(2019). "Analysis and Design of Castellated Beams". PHd. Thesis ALPlymouth University / School Engineering.

11. ASTM C618.(2019). "Standard Specification for Coal Fly Ash and Raw or Calcined Natural Pozzolan for Use in Concrete", ASTM International, West Conshohoken, PA, USA.

12. ASTM E 291-09. (2009). " Standard test method for Chemical Analysis of Caustic Soda and Caustic Potash (Sodium Hydroxide and Potassium Hydroxide) ", ASTM International, West Conshohoken, PA, USA.

13. ACI Committee 318M-19.(2019). "Building Code Requirements for Concrete and Commentary", American Concrete Institute, Farmington Hills, MI 48331, USA. 